\title{
Does Islamic Label Indicate Higher use of Trade Credit? Evidence from Sharī'ah Compliant Non-financial Firms in Pakistan
}

\author{
Muhammad Kamran ${ }^{1}$, Jaleel Ahmed ${ }^{2 *}$, Ikram Ullah ${ }^{3}$ \\ ${ }^{1}$ MS Scholar at Capital University of Science and Technology, Islamabad, Pakistan \\ ${ }^{2}$ Assistant Professor at Capital University of Science and Technology, Islamabad, Pakistan \\ ${ }^{3}$ Senior Lecturer at Faculty of Management Sciences, Riphah International University, Islamabad, Pakistan
}

\section{Keywords \\ Islamic Label (ISL) \\ Trade Credit (TC) \\ GMM}

Sharī'ah Compliance

Received: $13-\mathrm{Feb}-19$

Accepted: 7-Apr-19

\begin{abstract}
This study attempts to investigate the behavior of non-financial ISL firms towards usage of TC. In line with the previous literature, it is hypothesized that ISL "Sharī'ah Compliant" indicates higher use of TC by such firms, both demand and supply of TC. It is also hypothesized that TC is substitute of bank loan. The results are based on 338 non-financial firms listed on Pakistan Stock Exchange for 2008 to 2016 observation period. These include non-financial firms from all sectors. The study used random Generalized Method of Moment (GMM) estimation technique to explore the relationship of ISL and usage of TC as it is the most powerful method when sample size is large. The study found that ISL firms use more TC, as compared to conventional firms that have more access to bank loan. This study also found that firms with ISL prefer TC over the bank credit. The result of this study proves all stated hypotheses.
\end{abstract}

KAUJIE Classification: H23, Q2

JEL Classification: G11, H81, Z12

(C) 2019 JIBM. All rights reserved.

\section{INTRODUCTION}

TC is an external source of fund in corporate finance for a short time period. Brennan, Maksimovics, and Zechner (1988) defined the term TC as "an arrangement to buy goods or services on account, that is, without making immediate cash payment". Firms use TC in two perspectives; firstly, accounts receivable are generated when funds are provided to customers in rendering goods or services to them on account. Secondly, accounts payable are generated when suppliers provide funds by providing goods or services on account. From the perspectives of accounts payable and account receivables, firms determine their TC policy.

TC plays a significant role for firm financing \& investment and thus it flows like supply and demand channel from one to another (Carvalho \& Schiozer, 2015). TC is also considered

\footnotetext{
*Corresponding author: Jaleel Ahmed

†Email: dr.jaleel@cust.edu.pk
} 
as an alternative of bank credit when there are financial crises in an economy (Love, Preve, \& Sarria-Allende, 2007). When there is a time span between supply of goods and payments for goods, then TC takes place. According to Paul and Guermat (2008), TC is one of important financial instruments for the business; however, sometimes the researchers neglect it.

Alphonse, Ducret, and Séverin (2006) found that TC increases when there is a shortfall in banks debt. The study further refers that firms or individuals having low access to banks or low availability of banks financing, use TCs. The study by Schwartz (1974) analysed that TC had also an impact on money control. However, here a question may arise that, why do suppliers issue TC, whereas banks do not do so? The answer is that the suppliers have monetary advantages. Jain (2001) argues by answering the common question that TC by suppliers plays a role of financial intermediary between supplier(s) and borrower(s) and has advantages for both. The study further suggested that banks and suppliers both need evaluation and information about their customers to supply credit, whereas it is convenient for suppliers when compared with banks. Banks may have to get such information at a higher cost, while it is cheaper for suppliers because of long term relationship (Burkart \& Ellingsen, 2004). The study of Frank and Maksimovic (2004) also determines that TC is helpful for both suppliers and the clients purchasing on credit for fulfilling their financing and investing needs, especially when financial market is inefficient.

Islamic firms, like the conventional firm, need external financing for their operations, survival and growth. However, the way of meeting their required financing is quite different from other conventional firm because of many reasons and modes. The use of interest-based funds is prohibited in Islamic perspective because of prohibition of interest according to Sharī'ah (Islamic law). Islamic firms use different methods than the conventional firms for getting funds because of prohibition of interest on loan in Shari' ${ }^{-}$ah and the promotion of profit and loss sharing (Ayub, 2007). In this regard, many scholars argue that ISL firms use a very low level of debt in their operations. The study of Hayat and Hassan (2017) indicates a very low level of debts on the financial statement of the ISL firms. This attribute of debt level on balance sheet differentiates ISL firms from conventional firms (Adamsson Bouslah, \& Hoepner, 2014; Bhatt \& Sultan, 2012). Of course, with a low level of debts, ISL firms may use high level of TCs to meet their operational needs.

This empirical study explores the relationship between ISL 'Shari' 'ah compliant firms' and the behavior of non-financial sector firms towards higher use of TC. In this study, both the supply and demand of TC have been analyzed. Trade Credit Demand (TCD) has been measured by account payable, while the Trade Credit Supply (TCS) by account receivable on sales, taking as proxy. The study also provides evidence of TC as substitute of bank loan in non-financial sector in Pakistan. By using GMM technique, it is found that the firms with ISL 'Sharī'ah compliant firms' have significant impact on TC, that prefer TC over the bank credit or "conventional debt".

\section{LITERATURE REVIEW}

\section{ISL Firms}

ISL firms are those firms or companies that are operating according to Islamic finance 
principles. Islamic finance is a system in which all the operations of any firms have to be according to Islamic laws (Miglietta \& Salvi, 2013). Companies following rules and regulation of Sharī'ah are called as Sharī'ah Complaint. In the modern world, Islamic finance is an emerging segment for finance industry throughout the globe. The major goal of Islamic law is to maintain justice in the society (Chapra, 2008). According to Shari' ${ }^{6}$ ah, it is not possible to get success and prosperity in the nation without justice, and the prevalence of interest in the global finance is a big hurdle in doing justice with different groups and stakeholders in the societies (Ayub, 2007).

Some obligations implied by Shari ${ }^{-}$ah on Muslims in the business activities are to be just, fair, honest and truthful towards other. According to the study by Wilner (2000), Muslims are obliged to be honest, just and fair in their all of business activities towards other. The businesses that may inflict harm to the society are strictly prohibited for the Muslims and the firms that claim to be Shari 'ah compliant. The major objective of Shari'‘ ah is to establish friendly relations in all economic and financial activities among stakeholders (Rethel, 2011).

The Holy Qur'ann and the sayings of the Holy prophet laid the foundation of social and just economic system. Some basic actions and activities that are forbidden according to Islamic law, as indicated by Islamic scholars from all school of thoughts are highlighted here. The most important is rib $\bar{a}$ as also including 'interest' that is strictly forbidden by Sharí' $a$ ah in business or non-business activities (Ayub, 2002). Along with riba , excessive gharar (where the subject matter, the price, delivery to be made and outcome are uncertain), gambling or maysir and dealing in haräm products are strictly forbidden according to Sharī'ah. Investing in unethical business that is harmful for the society like alcohol, pornography and gambling is also strictly prohibited. However, Islamic law encourages investment in trade, but it should refrain from harām products. The investments should not be risk free to earn interest income, and there must be a stake of equity in it.

The principles relating to Islamic finance have been discussed in numerous studies. Around the globe, Muslims and non-Muslim researchers analyzed these principles of Islamic finance and the model of Islamic businesses (Iqbal \& Molyneux, 2005). However, there are few or negligible studies focusing on corporate finance based on Islamic finance (Brealey, Myers, \& Allen, 2014). Basically, Islamic finance indicates some activities that cannot be done in the business because the same are not allowed and lawful according to Sharī'ah (Biancone, 2012). The basic aim of Islamic finance as well as Sharī'ah is to encourage those activities, which could benefit the society and do not inflict any harm to the general public.

\section{TC}

TC is the oldest type of financing accessible for the buyers by the suppliers/sellers (Emery, 1987). TC suppliers have direct advantages over other financers. One such advantage is that suppliers are in a direct contact to their clients or buyers and can easily evaluate and monitor credit worthiness of their clients. Besides, suppliers have a fast and effective way of liquidating their assets in TC than other institutional financers.

According to Wilner (2000), the purpose of TC evidently shows liquidity motives for buyers and suppliers. Evans (1998) states that TC offered by suppliers are more profitable 
for supplier even in financial distress. Suppliers grant more concessions to buyers when there is distress in financial market and thus it should be marked as advantages for buyers as well. The findings of Petersen and Rajan (1997) and Evan (2000) further propose that seller opportunism also exists in TC, whereas buyers are dependent on suppliers (trade creditors). In the perspective of liquidity theory, a buyer's opportunism was firstly note by Peterson and Rajan (1997).

TCs have a cost advantage for both supplier and buyers, but may cause a problem of product quality for buyers. Smith (1987) highlighted that TC could be maintained in firms only if they maintain the quality of the products. On the other hand, some studies have indicated that TCs were more in those firms where quality of products was low. For example, Deloof and Jegers (1996) and Lee and Stowe (1993) studied TC, and found that the sellers in TC passed on low quality goods on high cost. According to Long, Malitz, and Ravid (1993) and Wei, Poon, and Zee (1997), large firms sell products of low quality on TC as compared to small firm because small firms are more careful about their reputations. These studies further suggest that in TC many industries provide less about quality of the products.

Santiago, Carbo-Valverde, Rodriguez-Fernandez, and Udell (2016) also studied relation of TC and bank credit and indicated that TC served as an alternative of bank credit for small businesses that face difficulties in availing finance from banks. McGuinness, Hogan, and Powell (2018) studied relationship between TC and financial distress and concluded that TC could be a source of alternative credit channel when banks loans are restricted. According to his study, TC availability reduces firms' financial distress by $21 \%$ on average for small and medium enterprises. Cole (2018) also studied credit usage of European firms. His interesting study relates to small firms. He found that $20 \%$ firms did not use credit at all, $20 \%$ firms used only TC, $20 \%$ used only bank credit, while remaining $40 \%$ used both TC and bank credit.

\section{ISL and TC}

The link between Islamic finance and TC has not been explained by the literature, but TC is strongly linked to many business operations. As according to Jensen (1986), TC was to be considered as the main source of external financing for the firms. In finance, there is only one alternate for debt and that is TC. According to many empirical evidences of the studies, TC is an alternative of debt and a good source of financing for the firm's business operations. As the firms with ISL cannot borrow on interest, they have to get TC for their working capital needs. On the basis of above literature and past studies, following hypothesis are developed:

H1: ISL firms have high level of TCD.

H2: ISL firms have high level of TCS.

\section{DATA \& METHODOLOGY}

\section{Data Description and Sample}

The sample has been taken form Pakistan Stock Exchange (PSX)-from all non-financial companies listed in PSX. The sample size consists of 338 firms and the period of observation involved 2008 to 2016. In this study, various industries in non-financial sector were kept in focus during sampling; such as oil \& gas, steel industry, refinery industry, textile, telecommu- 
nication and cement industries.

\section{Measurement of Variables}

For capturing the effect of TCD and supply, accounts receivable and accounts payable both have been used. TCD has been measured as accounts payable to debt, whereas TCS is measured as account receivable to sales ratio. The independent variable is ISL captured by dummy variable that takes the value of 1 if the firm is Shari ${ }^{-}$ah compliant, or otherwise 0 . The firms chosen as Sharī'ah compliant are those, which were listed as Sharī'ah compliant at that point of time when data was collected.

To investigate the relationship of ISL and TC, some company-specific variables have been used as control variables, which are derived from the previous literature. Control variables consist of firm size, leverage, sales growth, profitability, inventory, liquidity and FIX (fixed assets).

Firm size has been measured as natural log of assets; Leverage (LEV) is measured as debt to equity ratio; Sales Growth (SG) is the ratio of current year sales minus previous year sales divided by previous year sales. Profitability (PROF) is the ratio of Earning Before Interest and Taxes (EBIT) to total assets. Inventory (INVT) is measured as inventory to sales ratio. Liquidity (LIQ) is measured as cash to total assets. FIX is the ratio of fixed assets to total assets.

\section{Model Specification}

The econometric technique that considers the unobserved impact changing the factors into first difference and uses the GMM to deal with endogeneity issues. The following equations have been used in the study to measure the impact of ISL on TC.

$$
\begin{aligned}
T C D_{i, t}= & \begin{array}{l}
\beta_{0}+\beta_{1} T C D_{i, t-1}+\beta_{2} I S L_{i}+\beta_{3} S G_{i, t}+\beta_{4} P R O F_{i, t}+\beta_{5} I N V_{i, t}+\beta_{6} S I Z E_{i, t}+ \\
\beta_{7} L E V_{i, t}+\beta_{8} L I Q_{i, t}+\beta_{9} F I X_{i, t}+\varepsilon_{i, t}
\end{array} \\
T C S_{i, t}= & \begin{array}{l}
\beta_{0}+\beta_{1} T C S_{i, t-1}+\beta_{2} I S L_{i}+\beta_{3} S G_{i, t}+\beta_{4} P R O F_{i, t}+\beta_{5} I N V_{i, t}+\beta_{6} S I Z E_{i, t}+ \\
\beta_{7} L E V_{i, t}+\beta_{8} L I Q_{i, t}+\beta_{9} F I X_{i, t}+\varepsilon_{i, t}
\end{array}
\end{aligned}
$$

An interaction between LEVERAGE and ISLAMIC dummy is used in Equations (3) and (4) to study how ISL affects firms' use of TC by influencing the availability of bank credit.

$T C D_{i, t}=\begin{aligned} & \beta_{0}+\beta_{1} T C D_{i, t-1}+\beta_{2} I S L_{i}+\beta_{3} L E V_{i, t}+\beta_{4} I S L * L E V_{i, t}+\beta_{5} P R O F_{i, t}+\beta_{6} I N V_{i, t}+ \\ & \beta_{7} S I Z E_{i, t}+\beta_{8} S G_{i, t}+\beta_{9} L I Q_{i, t}+\beta_{10} F I X_{i, t}+\varepsilon_{i, t}\end{aligned}$

$\begin{aligned} T C S_{i, t}= & \beta_{0}+\beta_{1} T C S_{i, t-1}+\beta_{2} I S L_{i}+\beta_{3} L E V_{i, t}+\beta_{4} I S L * L E V_{i, t}+\beta_{5} P R O F_{i, t}+\beta_{6} I N V_{i, t}+ \\ & \beta_{7} S I Z E_{i, t}+\beta_{8} S G_{i, t}+\beta_{9} L I Q_{i, t}+\beta_{10} F I X_{i, t}+\varepsilon_{i, t}\end{aligned}$ 


\section{RESULTS AND DISCUSSION}

\section{Descriptive Statistics}

The results of descriptive analysis of all variables for ISL firms and conventional firms are reported in table Table 1 and 2 respectively.

TABLE 1

Descriptive Statistics ISL Firms and TC

\begin{tabular}{lllllllll}
\hline \hline & TCS & TCD & LEV & FIX & INVT & SG & PROF & LIQ \\
\hline Mean & 0.1111 & 0.4111 & 1.4362 & 0.6922 & 0.1635 & 0.1504 & 0.1127 & 0.0567 \\
Median & 0.0734 & 0.3482 & 1.1017 & 0.6565 & 0.1434 & 0.1115 & 0.1041 & 0.0209 \\
Maximum & 1.1044 & 1.2049 & 9.3840 & 1.9404 & 1.6189 & 6.5415 & 0.6198 & 0.5759 \\
Minimum & 0.0005 & 0.0203 & -6.7808 & 0.0532 & 0.0008 & -0.7979 & -0.2036 & 0.0002 \\
Std. Dev. & 0.1287 & 0.2657 & 1.4535 & 0.3449 & 0.1436 & 0.4486 & 0.1005 & 0.0874 \\
\hline \hline
\end{tabular}

TABLE 2

Descriptive Statistics Conventional Firms and TC

\begin{tabular}{lllllllll}
\hline \hline & TCS & TCD & LEV & FIX & INVT & SG & PROF & LIQ \\
\hline Mean & 0.1096 & 0.1161 & 1.7668 & 0.1849 & 0.0292 & 0.0868 & 0.2136 & 0.7626 \\
Median & 0.0752 & 0.0646 & 1.4911 & 0.1058 & 0.0100 & 0.0773 & 0.1978 & 0.7467 \\
Maximum & 0.7524 & 2.9663 & 12.2266 & 8.1849 & 0.5806 & 1.4334 & 0.7228 & 3.4419 \\
Minimum & 0.0000 & 0.0000 & -14.5377 & 0.0008 & 0.0001 & -1.0931 & 0.0002 & 0.0054 \\
Std. Dev. & 0.1160 & 0.1916 & 2.3097 & 0.3582 & 0.0529 & 0.1278 & 0.1355 & 0.3546 \\
\hline \hline
\end{tabular}

Tables 1 and 2 show the statistical summary of all variables included in this study. The sample mean value of TCS for Shari 'ah compliant firms is measured by accounts receivable to sales, which shows that accounts receivables to sale ratio is about $11.11 \%$, while for conventional firms it is $10.96 \%$. The mean value of TCD indicates accounts payable to debt ratio of about $41.11 \%$ for Sharī ah compliant firms and $11.61 \%$ for conventional firms.

The average ratio of Leverage (lev) is 1.44 for Shari ${ }^{\circ}$ ah compliant firms and 1.77 for conventional firms. The sample value of fixed assets to total assets is about $69.11 \%$ with a $34.49 \%$ standard deviation for Shari' ah firms and $18.49 \%$ with $35.82 \%$ for conventional firms. The average Inventory Rate (INVT) is $16.35 \%$ with standard deviation of $14.36 \%$ for Sharī'ah firms and $2.92 \%$ for conventional firms with standard deviation of 5.29\%. The average sales growth rate for Islamic firms is $15.04 \%$ and standard deviation $44.86 \%$ while mean value for conventional firms is $8.68 \%$ with SD of $12.78 \%$. Profitability rate of Islamic firms is $10 \%$ while for conventional firms it is $13.55 \%$. 


\section{Correlation Matrix and Multicollinearity}

TABLE 3

Correlations Among Variable

\begin{tabular}{lllllllll}
\hline \hline & TCD & TCS & LEV & LIQ & SG & INVT & PROF & FIX \\
\hline TCD & 1 & & & & & & & \\
TCS & $0.2544^{* *}$ & 1 & & & & & & \\
LEV & $-0.1136^{*}$ & $0.0656^{*}$ & 1 & & & & & \\
LIQ & $-0.475^{* *}$ & $-0.1279^{*}$ & $0.0708^{*}$ & 1 & & & & \\
SG & 0.0186 & -0.0129 & -0.0312 & $-0.1349^{*}$ & 1 & & & \\
INVT & $0.1398^{* *}$ & $-0.148^{*}$ & 0.0512 & -0.0821 & -0.0722 & 1 & & \\
PROF & $-0.2026^{* *}$ & $-0.0645^{*}$ & 0.0127 & $0.1768^{*}$ & $0.1058^{*}$ & $0.3569^{* *}$ & 1 & \\
FIX & $0.2868^{* *}$ & $-0.051^{*}$ & -0.0512 & $-0.59^{* * *}$ & 0.0150 & $-0.0698^{*}$ & $-0.412^{* *}$ & 1 \\
\hline \hline
\end{tabular}

* 10\% significance level, **5\% significance level, *** 1\% significance level

Table 3 comprises a correlation analysis of all variables used in this study. The TCD is positively correlated among TCS, SG, INVT and FIX, and negatively correlated with LEV, LIQ and PROF. TCS is also negatively correlated with LIQ, PROF, SG, and FIX. All other variables are in satisfactory correlation with each other.

ISL and TCD

TABLE 4

ISL \& TCD

\section{GMM}

Dependent Variable: TCD

Method: Panel GMM EGLS (Cross-section random effects)

Total panel (unbalanced) observations: 2209

Instrument specification: C TCD(-1) LEV LEV(-1) FIX(-1) SIZE(-1) LIQ(-1)PROF(-1) SG(-1)

\begin{tabular}{lllll}
\hline Variables & Co-efficient & Stranded-Error & $t$-Stat & Prob \\
\hline $\mathrm{C}$ & 0.051895 & 0.016825 & 3.084394 & 0.0021 \\
ISL & 0.069272 & 0.021277 & 3.255701 & 0.0011 \\
TCD(-1) & 0.786956 & 0.027764 & 28.34428 & 0.0000 \\
LEV & -0.00259 & 0.001236 & -2.09595 & 0.0362 \\
FIX & -0.06294 & 0.018591 & -3.38556 & 0.0007 \\
LIQ & 0.120243 & 0.054808 & 2.193906 & 0.0283 \\
SIZE & 0.000909 & 0.001655 & 0.549242 & 0.5829 \\
$R$-squared & 0.773979 & Instrument rank & 9 & \\
Adjusted $R$-squared & 0.773364 & $J$-statistic & 1.960838 & \\
Durbin-Watson stat & 1.996661 & Prob $(J$-statistic $)$ & 0.375154 & \\
\hline \hline
\end{tabular}

Table 4 explains the relationship between ISL and TCD. In this model, Leverage (LEV), FIX and Liquidity (LIQ) are the control variable. The result of ISL shows positive and significant impact on TCD at the level of ( $p$-value $\leq 0.05)$ with coefficient value $(\beta=$ 
0.069272). So, this analysis supports first hypothesis and proves that ISL firms tend to rely more on TCD rather than conventional credit (interest-based loan).

The firms' specific variable leverage was found negatively related with TCD and statistically significant, indicating that Islamic firms demand more credit as they avoid interest based debt (Hayat \& Hassan, 2017). These financial screens create a sub-set of low debt firms with possibly diverse factor than their conventional counterparts (e.g., Bhatt \& Sultan, 2012). FIX and Liquidity have been found significantly related with TCD with beta of -0.06294 and 0.120243 respectively.

\section{ISL and TCS}

TABLE 5

ISL \& TCS

\begin{tabular}{|c|c|c|c|c|}
\hline \multicolumn{5}{|l|}{ GMM } \\
\hline \multicolumn{5}{|c|}{ Dependent Variable: TCS } \\
\hline \multicolumn{5}{|c|}{ Method: Panel GMM EGLS (Cross-section random effects) } \\
\hline \multicolumn{5}{|c|}{ Total panel (unbalanced) observations: 2125} \\
\hline \multicolumn{5}{|c|}{ Instrument specification: C TCS(-1) LEV LEV(-1) LIQ(-1) SG(-1) INTSALES(-1) PROF(-1) FIX(-1) } \\
\hline Variables & Co-efficient & Stranded-Error & $t$-Stat & Prob \\
\hline $\mathrm{C}$ & 0.006615 & 0.013615 & 0.485848 & 0.6271 \\
\hline $\mathrm{TCS}(-1)$ & 0.913474 & 0.014599 & 62.57149 & 0.0000 \\
\hline ISL & 0.038906 & 0.014794 & 2.629825 & 0.0086 \\
\hline LEV & 0.002198 & 0.00063 & 3.487712 & 0.0005 \\
\hline SG & -0.18898 & 0.058809 & -3.21335 & 0.0013 \\
\hline INVT & -0.05778 & 0.029737 & -1.94314 & 0.0521 \\
\hline PROF & 0.082625 & 0.038888 & 2.124712 & 0.0337 \\
\hline FIX & 0.003245 & 0.012339 & 0.262965 & 0.7926 \\
\hline$R$-squared & 0.693031 & Instrument rank & 9 & \\
\hline Adjusted $R$-squared & 0.692016 & $J$-statistic & 0.264812 & \\
\hline Durbin-Watson stat & 2.113207 & $\operatorname{Prob}(J$-statistic $)$ & 0.606833 & \\
\hline
\end{tabular}

Table 5 shows that ISL is positively and significantly related with TCS at the level of ( $p \leq 0.05$ ) with coefficient value of $\beta=0.038906$. This explains the impact of Islamic finance on accounts receivable, in a way that Islamic firms use TC channel as compared to conventional firms. This analysis supports the second hypothesis and proves that firms with ISL (Sharí' ah compliance firms) tend to be relying more on TCS rather than conventional credit (interest-based loan).

The firms' specific factors sale growth and inventories are found negatively and statically significant with TCS, while leverage and profitability have positive and significant impact on TCS. On the other hand, FIX is found to have insignificant effect on TCS. 
ISL*Leverage and TCD

TABLE 6

Moderating effect of ISL on TCD

\section{GMM}

Dependent Variable: TCD

Method: Panel GMM EGLS (Cross-section random effects)

Total panel (unbalanced) observations: 2185

Instrument specification C TCD2(-1) LEV LEV(-1) FIX(-1) PROF(-1) LIQ(-1) SIZE(-1) SG(-1)

\begin{tabular}{lllll} 
Variable & Coefficient & Std. Error & $t$-Statistic & Prob. \\
\hline C & 0.123957 & 0.032399 & 3.825902 & 0.0001 \\
TCD2(-1) & 0.701183 & 0.044086 & 15.90482 & 0.0000 \\
ISL & 0.197355 & 0.057636 & 3.424176 & 0.0006 \\
LEV & 0.015468 & 0.009391 & 1.647102 & 0.0997 \\
ISL*LEV & -0.08749 & 0.04317 & -2.02662 & 0.0428 \\
FIX & -0.16676 & 0.039467 & -4.22537 & 0.0000 \\
PROF & -0.2021 & 0.120608 & -1.67566 & 0.0939 \\
SG & 0.216261 & 0.13408 & 1.612927 & 0.1069 \\
$R$-squared & 0.561127 & Instrument rank & 9 & \\
Adjusted $R$-squared & 0.559716 & $J$-statistic & 2.587439 & \\
Durbin-Watson stat & 1.772279 & Prob $(J$-statistic $)$ & 0.107714 & \\
\hline
\end{tabular}

The second keen interest of this study is to check the combined effect of ISL and leverage so that effect of ISL can be examined on firms' use of TC in the presence of availability of debt. For this purpose, an interaction between ISL firm dummy and leverage have been analysed.

The result of ISL and leverage interaction has been found statistically significant at level of $(p \leq 0.05)$ as the value of coefficient $(\beta=-0.08749)$ show inverse relationship between ISL dummy and leverage interaction with TCD. This finding is consistent with Marc and Wouter (2010). So, TC is a tool of financing in case of unavailability of bank credit (Marc \& Wouter, 2010). 


\section{ISL Leverage and TCS}

TABLE 7

Moderating effect of ISL on TCS

\begin{tabular}{|c|c|c|c|c|}
\hline \multicolumn{5}{|l|}{ GMM } \\
\hline \multicolumn{5}{|c|}{ Dependent Variable: TCS } \\
\hline \multicolumn{5}{|c|}{ Method: Panel GMM EGLS (Cross-section random effects) } \\
\hline \multicolumn{5}{|c|}{ Total panel (unbalanced) observations: 2157} \\
\hline \multicolumn{5}{|c|}{ Instrument specification TCS(-1) LEV LEV(-1) LIQ(-1) INTSALES(-1)PROF(-1) SG(-1) SIZE(-1) } \\
\hline Variables & Coefficient & Stranded Error & $t$-Statistic & Prob \\
\hline $\mathrm{C}$ & 0.004297 & 0.008105 & 0.530108 & 0.5961 \\
\hline $\mathrm{TCS}(-1)$ & 0.929582 & 0.021334 & 43.57323 & 0.0000 \\
\hline ISL & 0.064124 & 0.038035 & 1.685925 & 0.0920 \\
\hline LEV & 0.012551 & 0.005754 & 2.181328 & 0.0293 \\
\hline ISL*LEV & -0.05358 & 0.027044 & -1.98134 & 0.0477 \\
\hline LIQ & 0.00682 & 0.031559 & 0.216122 & 0.8289 \\
\hline PROF & -0.07148 & 0.028913 & -2.47228 & 0.0135 \\
\hline SIZE & 0.000144 & 0.000991 & 0.145189 & 0.8846 \\
\hline$R$-squared & 0.625141 & Instrument rank & 9 & \\
\hline Adjusted $R$-squared & 0.62392 & $J$-statistic & 0.743674 & \\
\hline Durbin-Watson stat & 1.688833 & Prob ( $J$-statistic) & 0.388486 & \\
\hline
\end{tabular}

In Table 7, ISL firms' leverage and TCS have been examined. The interaction term is used to check the combined effect of leverage and Shari' 'ah compliance on TCS. The above table shows that the $\mathrm{P}$ value of $\mathrm{C}$ is 0.5961 , found statically insignificant, it means there is no omitted variable bias. The result of ISL and leverage interaction has been found statistically significant at level $(p \leq 0.05)$ as the value of coefficient $(\beta=-0.05358)$ which shows negative relation between ISL dummy and leverage interaction with TCS. Therefore, this study proves that TC is substitute of bank credit. Results of the study are in line with the previous researches. According to Meltzer's (1960), TC can be substituted with the bank credit. TC is the better option when financing from commercial bank is limited (Burkart \& Ellingsen 2002). According to Demirguc-Kunt and Maksimovic, (2002), Marotta, (1997), and Nilsen (2002) TC is a good choice for short-term financing and building new customer relation.

The above result also shows the firms specific variable leverage $(\beta=0.012551)$ and $(p$-value $\leq 0.05$ ) found positive and significant relationship with TCS. These results are in line with Molina and Preve (2012) and Seifert, Seifert, and Protopappa-Sieke, (2013). Profitability is found significantly positively related with TCS while liquidity and size are found insignificant.

As there is no virtually existing literature on this domain, this is first empirical study, which proves the positive and significant impact of ISL on TC, and may be a good sign for encouragement for Islamic banking. In fact, Islamic Banking is growing very fast. Hence, these findings will help to increase attention towards Islamic banking industry. So, this result confirms that ISL firms are interested to provide more TC to customers. 


\section{CONCLUSION AND RECOMMENDATIONS}

This empirical study explores the relationship between firm with ISL and use of TC. For this purpose, data of 338 non-financial firms listed on Pakistan Stock Exchange have been collected for analysis from the year 2008 to 2016. In this study both TCD and supply of TC have been analyzed; while TCD is measured by accounts payable to debt, for TCS accounts receivable to sale proxy has been used. This study provides evidence of TC as substitute of bank loan in non-financial sector of Pakistan.

Moreover, after applying the GMM estimation technique, it is found that ISL or 'Sharī'ah compliant firms' have significant impact on TC, and also prefer TC over bank credit (conventional debt). This is one of the first study that established empirical evidence of higher usage of TC in Sharī'ah compliant firms. In addition, this study suggests that ISLs firms are significantly associated with both TCD and supply. Furthermore, TC is significant source of financing for Sharī'ah compliant firms, as bank loan is not used in a way as conventional firms use it. It is also observed that firms which having higher level of inventory are less interested to promote TC, but more interested to collect goods on account from suppliers. As the study highlighted the use of other secondary sources of finance in ISL firms, it is suggested, for policy makers, that TC is a better substitute for conventional bank lending. Therefore, it is necessary to adopt other secondary sources of finance like TC.

\section{REFERENCES}

Adamsson, H., Bouslah, K., \& Hoepner, A., (2014). An Islamic equity premium puzzle (ICMA working paper). Reading, England: Henley Business School, University of Reading.

Alphonse, P., Ducret, J., \& Séverin, E. (2006). When trade credit facilitates access to bank finance: Evidence from US small business data. In MFS Meetings Paper, Istanbul, Turkey.

Ayub, M. (2002). Islamic banking and finance: Theory and practice. Karachi, Pakistan: State Bank of Pakistan.

Ayub, M. (2007). Understanding Islamic finance. Chichester, UK: John Wiley and Sons. Bhatt, V., \& Sultan, J. (2012). Leverage risk, financial crisis, and stock returns: A comparison among Islamic, conventional, and socially responsible stocks. Islamic Economic Studies, $130(552), 1-57$.

Biancone, P. P. (2012). The balance sheet of the Islamic bank and the representation of the main financial contracts. Milan, Italy: Franco Angeli.

Brealey, R. A., Myers, S. C., \& Allen, F. (2014). Principle of corporate finance. Berkshire, UK: McGraw-Hill Education.

Brennan, M. J., Maksimovics, V., \& Zechner, J. (1988). Vendor financing. The Journal of Finance, 43(5), 1127-1141. doi: https://doi.org/10.1111/j.1540-6261.1988.tb03960.x

Burkart, M., \& Ellingsen, T. (2004). In-kind finance: A theory of trade credit. American Economic Review, 94(3), 569-590. doi: https://doi.org/10.1257/0002828041464579 
Carbo-Valverde, S., Rodriguez-Fernandez, F., \& Udell, G. F. (2016). Trade credit, the financial crisis, and SME access to finance. Journal of Money, Credit and Banking, 48(1), 113-143. doi: https://doi.org/10.1111/jmcb.12292

Carvalho, C. J. D., \& Schiozer, R. F. (2015). Determinants of supply and demand for trade credit by micro, small and medium-sized enterprises. Revista Contabilidade $\mathcal{E}$ Finanças, 26(68), 208-222. doi: https://doi.org/10.1590/1808-057x201500940

Chapra, M. U. (2008). Innovation and authenticity in Islamic finance. In Eight Harvard Conference in Islamic Finance, Massachusetts, MA.

Cole, R. A. (2018). Bank credit, trade credit or no credit: Evidence from the surveys of small business finances. Retrieved from https://bit.ly/2SWIPB1

Deloof, M., \& Jegers, M. (1996). Trade credit, product quality, and intragroup trade: Some European evidence. Financial Management, 25(3), 33-43.

Demirguc-Kunt, A., \& Maksimovic, V. (2002). Firms as financial intermediaries: Evidence from trade credit data (WPS2696). Washington, DC, WA: World Bank.

Emery, G.W. (1984). A pure financial explanation for trade credit. Journal of Financial and Quantitative Analysis 19, 271-285. doi: https://doi.org/10.2307/2331090

Evans, J. D. (1998). Are lending relationships valuable to equity holders in chapter 11 bankruptcy (Unpublished manuscript). Georgia State University, Atlanta, Georgia

Frank, M. Z., \& Maksimovic, V. (2004). Trade credit, collateral, and adverse selection (Working paper MD 20742). College Park, MD: University of Maryland.

Hayat, R., \& Hassan, M. K. (2017). Does an Islamic label indicate good corporate governance? Journal of Corporate Finance, 43, 159-174. doi: https://doi.org/10.1016/j.jcorpfin.2016.12.012

Iqbal, M., \& Molyneux, P. (2005). Thirty years of Islamic banking. History, performance and prospects. New York, NY: Palgrave Macmillan

Jain, N. (2001). Monitoring costs and trade credit. The Quarterly Review of Economics and Finance, 41(1), 89-110. doi: https://doi.org/10.1016/s1062-9769(00)00063-6

Jensen, M. C. (1986). Agency costs of free cash flow, corporate finance, and takeovers. The American Economic Review, 76(2), 323-329.

Lee, Y. W., \& Stowe, J. D. (1993). Product risk, asymmetric information, and trade credit. Journal of Financial and Quantitative Analysis, 28(2), 285-300. doi: https://doi.org/10.2307/2331291

Long, M. S., Malitz, I. B., \& Ravid, S. A. (1993). Trade credit, quality guarantees, and product marketability. Financial Management, 22(4), 117-127.

doi: https://doi.org/10.2307/3665582

Love, I., Preve, L. A., \& Sarria-Allende, V. (2007). Trade credit and bank credit: Evidence from recent financial crises. Journal of Financial Economics, 83(2), 453-469. doi: https://doi.org/10.1016/j.jfineco.2005.11.002

McGuinness, G., Hogan, T., \& Powell, R. (2018). European trade credit use and SME survival. Journal of Corporate Finance, 49, 81-103. doi: https://doi.org/10.1016/j.jcorpfin.2017.12.005 
Meltzer, H. (1960). Mercantile credit, monetary policy, and size of firms. The Review of Economics and Statistics, 42, 429-437. doi: https://doi.org/10.2307/1925692

Miglietta, N., \& Salvi, A. (2013). Islamic finance principles. Bari, Italy: Cacucci Publisher

Molina, C. A., \& Preve, L. A. (2009). Trade receivables policy of distressed firms and its effect on the costs of financial distress. Financial Management, 38(3), 663-686. doi: https://doi.org/10.1111/j.1755-053x.2009.01051.x

Nilsen, J. H. (2002). Trade credit and the bank lending channel. Journal of Money, Credit, and Banking, 34(1), 226-253. doi: https://doi.org/10.1353/mcb.2002.0032

Paul, S. Y., \& Guermat, C. (2008). Trade credit as short-term finance in the UK (Working paper 10/09). Bristol, UK: University of the West of England,

Petersen, M. A., \& Rajan, R. G. (1997). Trade credit: Theories and evidence. The Review of Financial Studies, 10(3), 661-691. doi: https://doi.org/10.1093/rfs/10.3.661

Rethel, L. (2011). Whose legitimacy? Islamic finance and the global financial order. Review of International Political Economy, 18(1), 75-98.

doi: https://doi.org/10.1080/09692290902983999

Schwartz, R. A. (1974). An economic model of trade credit. Journal of Financial and Quantitative Analysis, 9(4), 643-657. doi: https://doi.org/10.2307/2329765

Seifert, D., Seifert, R. W., \& Protopappa-Sieke, M. (2013). A review of trade credit literature: Opportunities for research in operations. European Journal of Operational Research, 231(2), 245-256. doi: https://doi.org/10.1016/j.ejor.2013.03.016

Smith, J. K. (1987). Trade credit and informational asymmetry. The Journal of Finance, 42(4), 863-872. doi: https://doi.org/10.1111/j.1540-6261.1987.tb03916.x

Wei, P., Poon, P., \& Zee, S. (1997). The effect of option listing on bid-ask spreads, price volatility, and trading activity of the underlying OTC stocks. Review of Quantitative Finance and Accounting, 9(2), 165-180. doi: https://doi.org/10.1023/A:1008212525953

Wilner, B. S. (2000). The exploitation of relationships in financial distress: The case of trade credit. The Journal of Finance, 55(1), 153-178.

doi: https://doi.org/10.1111/0022-1082.00203 